Brazilian Journal of Animal Science ISSN 1806-9290

www.rbz.org.br

\section{Genetic evolution of milk yield, udder morphology and behavior in Gir dairy cattle}

\author{
André Rabelo Fernandes $^{1}$ (iD, Lenira El Faro ${ }^{2}$ iD, Anibal Eugênio Vercesi \\ Filho $^{2}$, Carlos Henrique Cavallari Machado ${ }^{3}$, Leandro Martins Barbero ${ }^{4}$, \\ Eustáquio Resende Bittar ${ }^{5}$, Mauricio Scoton Igarasi ${ }^{{ }^{*}}$ (iD) \\ ${ }^{1}$ Associação Brasileira dos Criadores de Gir Leiteiro, Uberaba, MG, Brasil. \\ ${ }^{2}$ Instituto de Zootecnia, Sertãozinho, SP, Brasil. \\ ${ }^{3}$ Faculdades Associadas de Uberaba, Uberaba, MG, Brasil. \\ ${ }^{4}$ Universidade Federal de Uberlândia, Uberlândia, MG, Brasil. \\ ${ }^{5}$ Universidade de Uberaba, Faculdade de Medicina Veterinária, Uberaba, MG, Brasil.
}

\section{*Corresponding author:} mauricio.igarasi@uniube.br

Received: March 23, 2018

Accepted: March 16, 2019

How to cite: Fernandes, A. R.; El Faro, L.; Vercesi Filho, A. E.; Machado, C. H. C.; Barbero, L. M.; Bittar, E. R. and Igarasi, M. S. 2019. Genetic evolution of milk yield, udder morphology and behavior in Gir dairy cattle. Revista Brasileira de Zootecnia 48:e20180056.

https://doi.org/10.1590/rbz4820180056

Copyright: This is an open access article distributed under the terms of the

Creative Commons Attribution License (http://creativecommons.org/licenses/by/4.0/), which permits unrestricted use, distribution, and reproduction in any medium, provided the original work is properly cited.

\begin{abstract}
The objective of this study was to analyze the genetic evolution of milk production, udder morphology, and animal behavior of Gir dairy cattle. Data were obtained on the predicted breeding values for milk yield of 60,226 cows born from 1968 to 2015 and standardized predicted breeding values for udder conformation and milking behavior of 7,635 cows born from 1987 to 2015 . The influence of tested bulls on genetic trends was discussed, with special focus on the period after 1993, the year when the predicted breeding values of the first group of tested bulls were released. The traits of interest were 305-d milk yield, fore udder attachment, rear udder height, rear udder width, teat length, teat thickness, ease of milking, and reactivity. Significant genetic evolution was observed for 305-d milk yield, with increasing annual growth observed from 1993, as the number of cows sired by the best proven bulls increased. Before 1993, no genetic evolution was observed for any of the studied traits. From 1993 onward, all traits showed genetic gains, except fore udder attachment. The use of geneticallytested bulls since 1993 has led to important genetic gains in the Brazilian Dairy Gir population. Before the identification of genetically superior bulls began, many traits showed no improvement. Selection for milk yield has modified the conformation traits of the Gir mammary system. The longevity of the mammary glands of high-yield cows may be impaired due to poor fore udder attachment. Regarding behavioral traits, this population has evolved to less-reactive animals that are easier to milk.
\end{abstract}

Keywords: linear traits, mammary system, reactivity, teat morphology, udder attachment

\title{
(c))BY
}

\section{Introduction}

The Dairy Gir is the result of selective breeding since the 1930s of Gir cattle (Bos taurus indicus) originally imported from India (Leão et al., 2013). Selective breeding has been practiced empirically for more than 50 years, and the Associação Brasileira de Criadores de Gir Leiteiro (ABCGIL) and Embrapa Gado de Leite began the "Programa Nacional de Melhoramento do Gir Leiteiro" (PNMGL - National Dairy Gir Breeding Program) in 1985. The main objective of the PNMGL is to promote the genetic improvement of Dairy Gir for production, conformation, and handling (Panetto et al., 2017).

Breeding programs primarily emphasize increased milk yield and its constituents (Prata et al., 2015). However, to optimize both yield and longevity, it is indispensable that the morphological structure and body condition sustain production and continue in the herd. However, for optimized production, 
which includes milk yield and productive lifespan, it is indispensable that the breed have a morphological structure and body condition capable of maintaining production and permanence in the herd (Freitas et al., 2002; Campos et al., 2012; Almeida et al., 2017; Saowaphak et al., 2017). According to Lagrotta et al. (2010) and Saowaphak et al. (2017), conformation traits are of extreme importance for dairy cattle breeding, since they provide greater production system efficiency. Behavioral traits are also important, since reactivity and ease of milking are also fundamental for greater efficiency.

In the dairy cattle selection process, emphasis is given to production-related traits, since high-production animals generate more revenue. In general, selection for milk yield alone may reduce the merit of other traits (Misztal et al., 1992; Campos et al., 2012; Saowaphak et al., 2017). Thus, it is necessary to evaluate the association between milk yield and other traits, highlighting their evolution during selection for milk yield.

Therefore, the objective of this study was to analyze the genetic evolution of milk yield, mammary system morphology, and behavioral traits in the genetic improvement of the Brazilian Dairy Gir.

\section{Material and Methods}

The database used to study milk yield, mammary system morphology, reactivity, and ease of milking was obtained from the PNMGL, which is led by the ABCGIL and Embrapa Gado de Leite since 1985. The first battery of proven bulls was released in 1993.

The genetic trend of milk yield was observed for 60,226 females, born from 1968 to 2014, for which such records were available. The genetic trends of udder conformation and milk behavior traits were observed for 7,635 cows born from 1987 to 2015.

Data collection on lactating Dairy Gir females was conducted using methodology from the PNMGL linear-type traits (Embrapa Gado de Leite, 2005). Fore udder attachment was visually assessed and scored from 1 to 9, with 1 indicating weak attachment and 9 indicating an overly strong one. Rear udder height was visually assessed, scored from 1 to 9 , obtained by the observation of the distance from the top to the bottom of the udder, with increasing scores indicating increasing capacity for milk storage, but also increased proneness to trauma. Rear udder width was visually assessed and scored from 1 to 9 , with 1 indicating a very narrow udder, 9 indicating a very wide one, with greater capacity for milk storage. Teat length was obtained by measuring the length of the teat, which corresponds to the distance between the tip of the teat and its insertion in the udder, with a ruler or tape measure, also converted to a score, with 1 indicating a small teat and 9 indicating a very large teat. Teat thickness was obtained by measuring teat diameter at its midsection with a ruler or tape measure and also converted to a score, with 1 indicating the thinnest teat and 9 indicating the thickest. Ease of milking was scored from 1 to 9 , with 1 indicating animals that are very easy to milk, 9 indicating those very difficult to milk. Reactivity was also scored from 1 to 9 , with 1 indicating the least reactive animals and 9 indicating the most reactive ones. This trait was based on the animal response to external stimuli while the other measurements were being performed.

For accumulated milk yield until the 305th day in milk, the model included animal random effects (direct genetic and permanent environmental effects), as well as the fixed effects of contemporary groups and age of cow at calving as covariates (linear and quadratic effects). The contemporary groups were defined by farm, year, and calving season, i.e., rainy (from October to March) or dry (from April to September) season. Records from cows that changed herds during lactation were not considered in the analyses.

The mean and standard deviations of all contemporary groups were used, which reduced cases of extreme production. Contemporary groups with fewer than three observations were eliminated from the analyses, as were any cases of yield 3.5 standard deviations above or below the group average. Each trait was analyzed considering random effects (animal additive genetic and permanent environmental effects), as well as the fixed effects of contemporary groups, evaluator, and cow age at the time of evaluation as covariates (linear and quadratic effects). The contemporary groups for linear traits were defined by farm and by year and season of the evaluation. The variance components were estimated 
by the restricted maximum likelihood method under an animal model, using the MTDFREML statistical package (Boldman et al., 1995).

In matrix notation, the model can be represented as:

$$
\mathrm{y}=\mathrm{Xb}+\mathrm{Za}+\mathrm{Wpe}+\mathrm{e},
$$

in which $\mathrm{y}=$ vector of observations for milk yield, linear, and management traits; $\mathrm{b}=$ vector of fixed effects (contemporary groups and age at calving for milk yield and contemporary groups, evaluator, and age at the time of evaluation for the other traits); a = vector of solutions for additive genetic random effect; $\mathrm{pe}=$ vector of solutions for animal permanent environmental random effect; $\mathrm{X}, \mathrm{Z}$, and $\mathrm{W}=$ correspondent incidence matrices for fixed and additive genetic and permanent environmental random effects, respectively; and e = vector of the residuals.

The breeding values predicted for the animals were obtained through Best Linear Unbiased Prediction (BLUP) solutions of the mixed-model equations. Each genetic value for milk yield is presented in the form of predicted transmitting ability (PTA). Regarding mammary system conformation traits, reactivity, and ease of milking, the genetic values are presented as standard transmitting abilities (STA), i.e., the PTA value divided by the genetic standard deviation of the trait under analysis. Thus, each STA is expressed in standard deviation units and not in the original unit of the trait. The STA allows the different traits to be compared and their most extreme values to be known.

The genetic trend for each trait was described by using linear- and quadratic-regression ANOVA. The regression was divided into two periods: before and after 1993, the year in which PNMGL-tested bulls began to be used. Linear traits were evaluated from 1987 to 2015, with measurements beginning in 1994. Milk yield could be evaluated from 1968 to 2015, due to the availability of data collected by ABCGIL before implementation of the PNMGL. The significance level was set at $5 \%(\mathrm{P}<0.05)$.

\section{Results}

The data for each trait (milk yield, udder morphology, and behavioral traits) are presented in two periods. This division served to better analyze the impact of PNMGL as a reference point for discussions on genetic trends. This study also assessed the evolution of the evaluated means according to year of birth after the program had been established (Figures 1 to 8).

Milk yield grew significantly since the implementation of the PNMGL (Figure 1). Although both regression equations, i.e., before (linear effect, $R^{2}=0.39$ ) and after (quadratic effect, $R^{2}=0.96$ ) 1993, were significant (both $\mathrm{P}<0.001$ ), genetic gain was only observed after 1993, i.e., after the program.

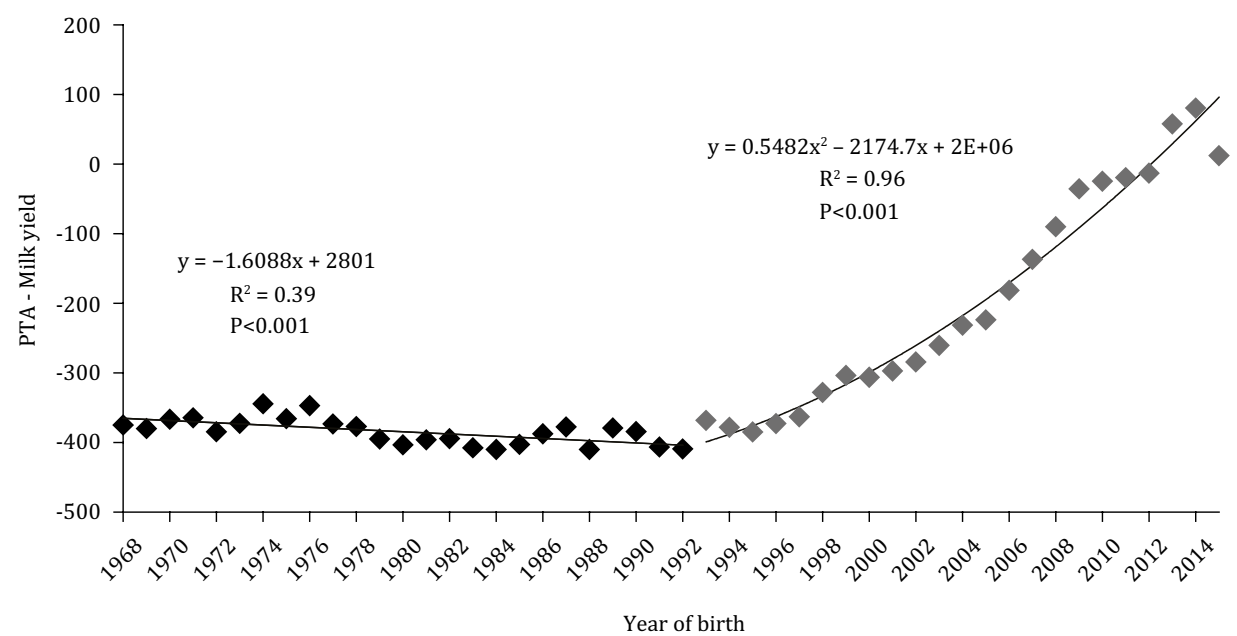

PTA - predicted transmitting ability.

Figure 1 - Mean Dairy Gir milk yield (PTA) according to year of birth. 
The regression line was not significant $(\mathrm{P}=0.193)$, indicating no evolutionary trend explainable by a linear mathematical equation. After 1993 , however, a significant quadratic regression $(\mathrm{P}<0.001)$ explained the reduction in the genetic value of fore udder attachment (Figure 2). The genetic value of rear udder height was not significant until $1993\left(\mathrm{P}=0.829 ; \mathrm{R}^{2}=0.01\right)$; it has increased since then $\left(P<0.001 ; R^{2}=0.79\right)$ (Figure 3). Likewise, prior to 1993, no linear effect was observed for rear udder width $\left(P=0.269 ; R^{2}=0.29\right)$, whereas genetic gains (quadratic effect) were found for this trait after $1993\left(\mathrm{P}<0.001 ; \mathrm{R}^{2}=0.92\right)$ (Figure 4).

Genetic gain in teat length was only observed in animals born after $1993\left(\mathrm{P}<0.001 ; \mathrm{R}^{2}=0.63\right)$ (Figure 5). Teat thickness (Figure 6) followed the same trend toward reduction found in teat length $(\mathrm{P}<0.001$; $\mathrm{R}^{2}=0.64$ ) due to the fact that they are directly associated. There were no genetic evolution in teat length $\left(P=0.273 ; R^{2}=0.28\right)$ and teat diameter $\left(P=0.691 ; R^{2}=0.04\right)$ prior to 1993.

Behavioral traits were also altered by the use of proven bulls. Before the implementation of the breeding program in 1993, there was no effect on STA values for ease of milking $\left(\mathrm{P}=0.100 ; \mathrm{R}^{2}=0.53\right)$ (Figure 7)

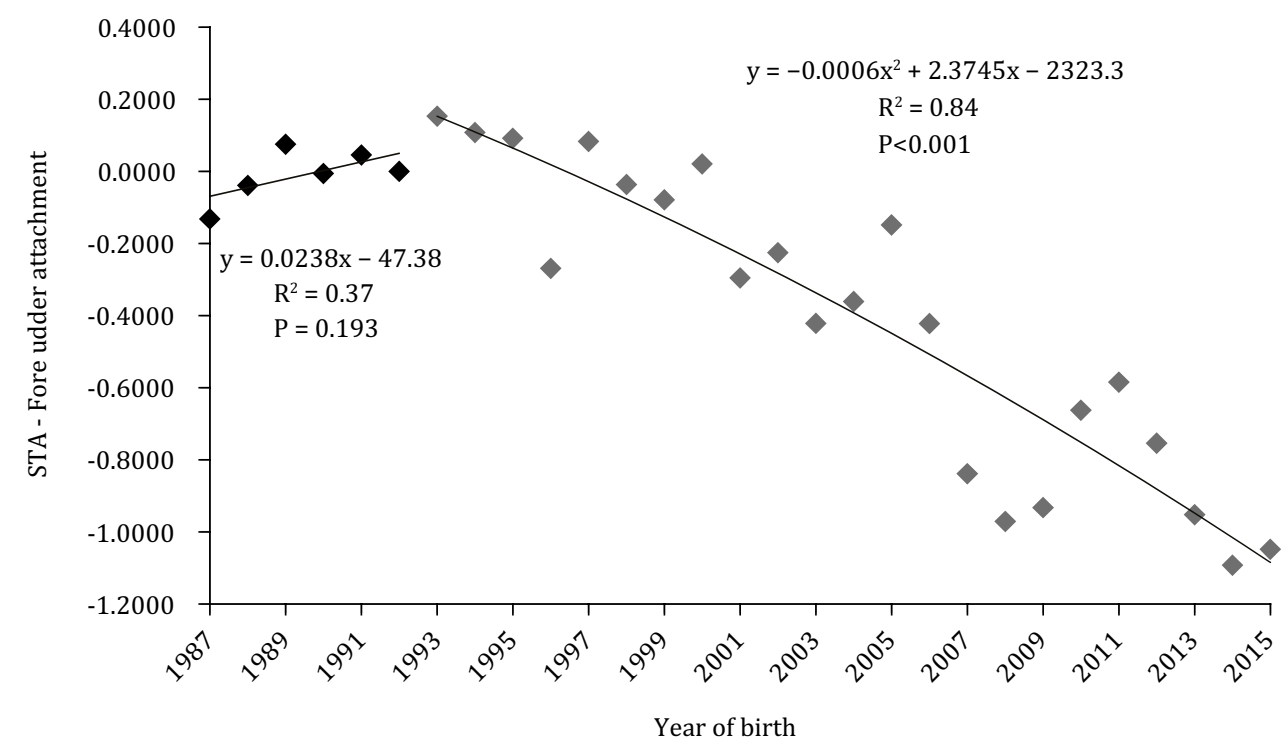

STA - standard transmitting ability.

Figure 2 - Mean Dairy Gir fore udder attachment STA according to year of birth.

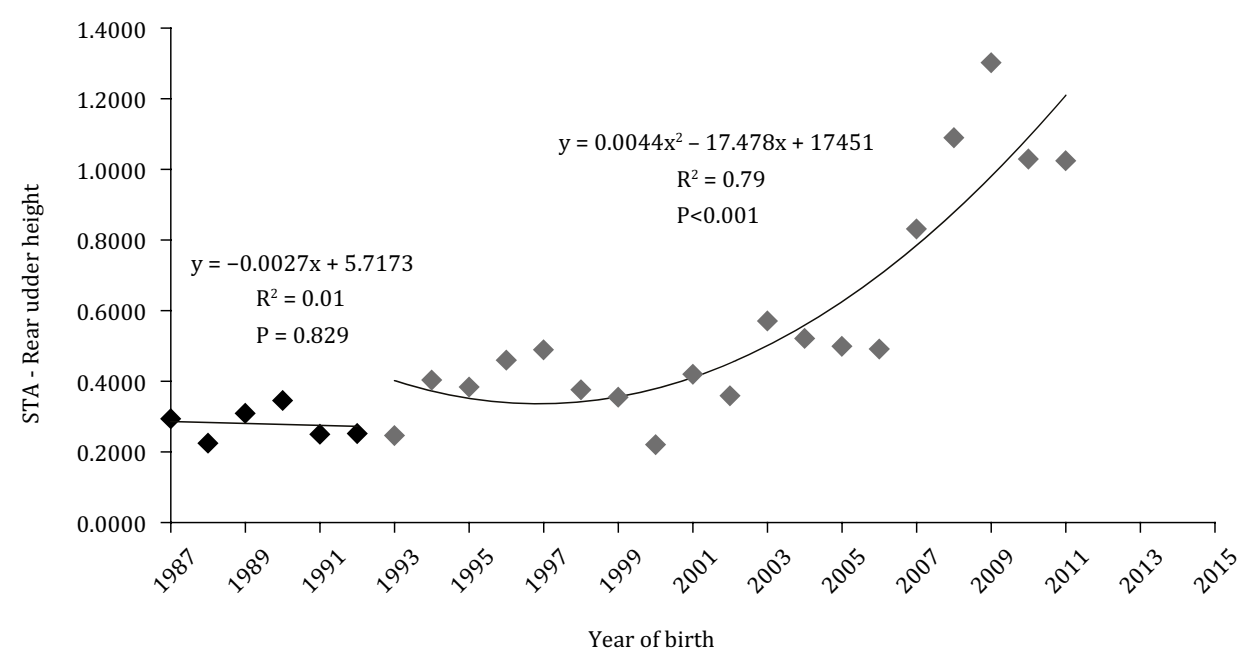

STA - standard transmitting ability.

Figure 3 - Mean Dairy Gir rear udder height STA according to year of birth. 
5

Genetic evolution of milk yield, udder morphology and behavior in fir dairy cattle

Fernandes et al.

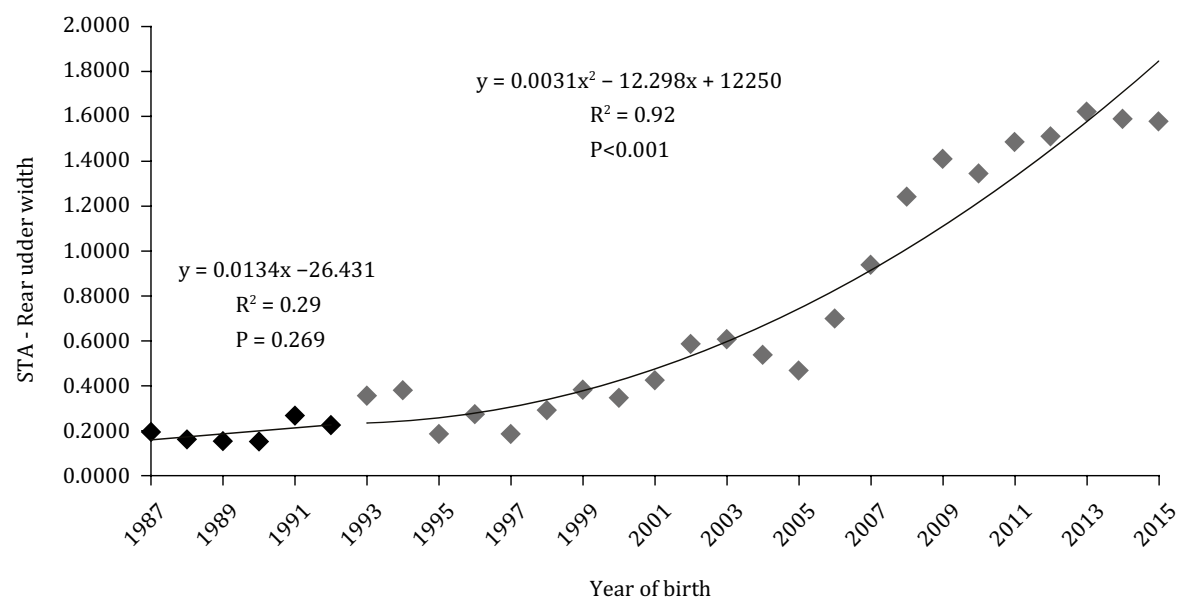

STA - standard transmitting ability.

Figure 4 - Mean Dairy Cir rear udder width STA according to year of birth.

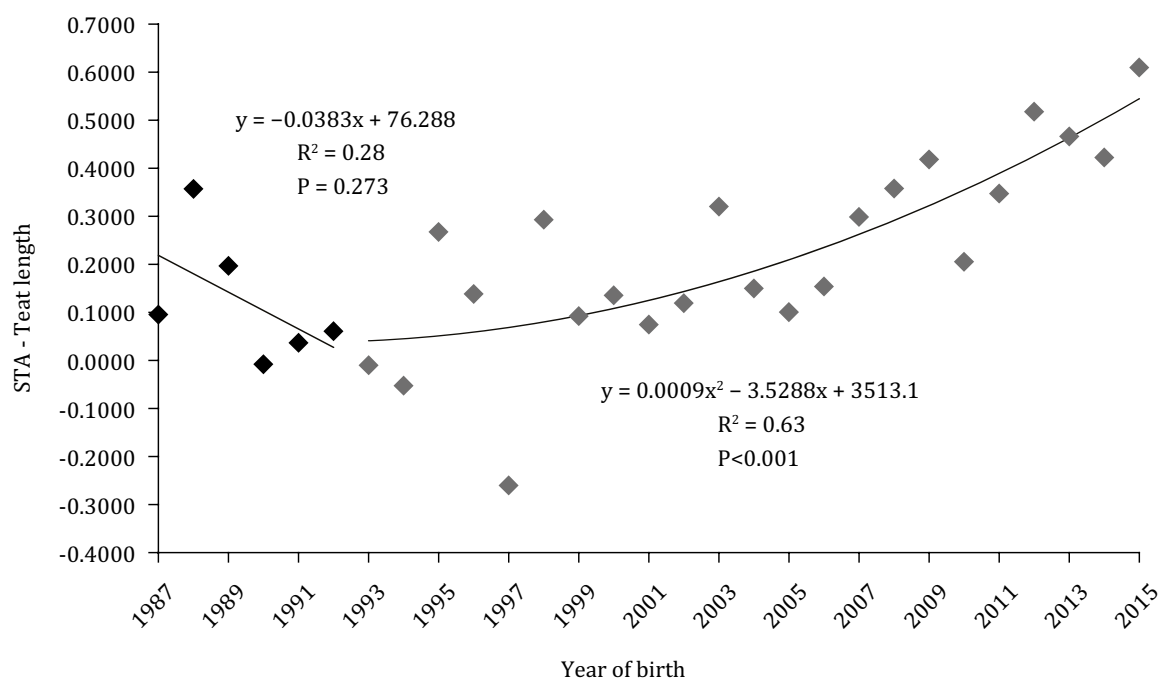

STA - standard transmitting ability.

Figure 5 - Mean Dairy Fir teat length STA according to year of birth.

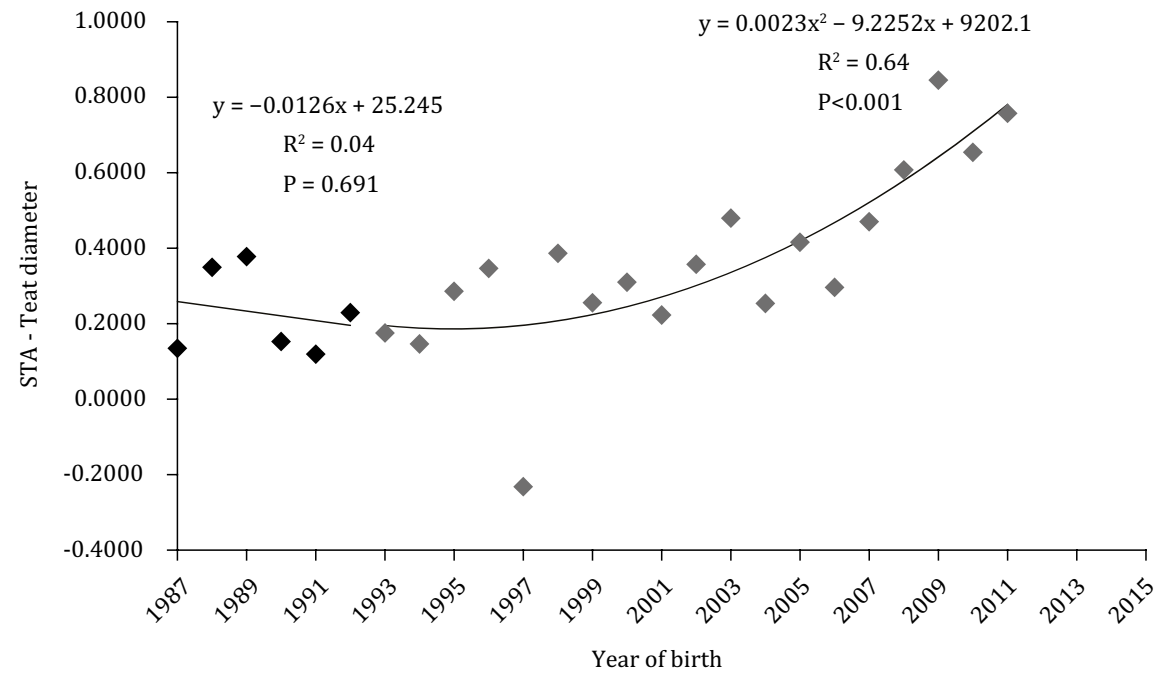

STA - standard transmitting ability.

Figure 6 - Mean Dairy Cir teat diameter STA according to year of birth.

R. Bras. Zootec., 48:e20180056, 2019 
or reactivity $\left(P=0.730 ; R^{2}=0.03\right)$ (Figure 8), representing no genetic gains. Since 1993, there has been a change in linear trend for ease of milking $\left(\mathrm{P}<0.001 ; \mathrm{R}^{2}=0.77\right)$ and reactivity $\left(\mathrm{P}<0.001 ; \mathrm{R}^{2}=0.87\right)$, revealing genetic gains with the reduction in STA.

\section{Discussion}

This study aimed to analyze the genetic evolution of milk yield, udder morphology, and animal behavior in Gir dairy cattle before and after the implementation of the breeding program (PNMGL) and the use of tested bulls. Milk yield responded to the selection process, and the system implemented to increase production achieved greater genetic gains after 1993. There was a quadratic effect in genetic gain in milk yield as expressed by PTA (Figure 1). The PNMGL was introduced in 1987, and the first battery of proven bulls was released to the market in 1993. From this point on, an accelerated increase in mean for milk yield was observed as a consequence of the greater selection pressure by breeders through the use of selected bulls.

After initiating breeding programs similar to that used with Dairy Gir, improved mean milk yield was also observed in Brazilian Girolando (Silva et al., 2014), which is a cross between Gir and Holsteins. The genetic gains were also partially due to the improvements in Dairy Gir, since they contribute an average of $37.5 \%$ of the genetic makeup of Girolando.

Fore udder attachment is of great importance in dairy cows, since it guarantees the support and integrity of the udder, which must be well adhered to the abdomen of the cow (Lagrotta et al., 2010).

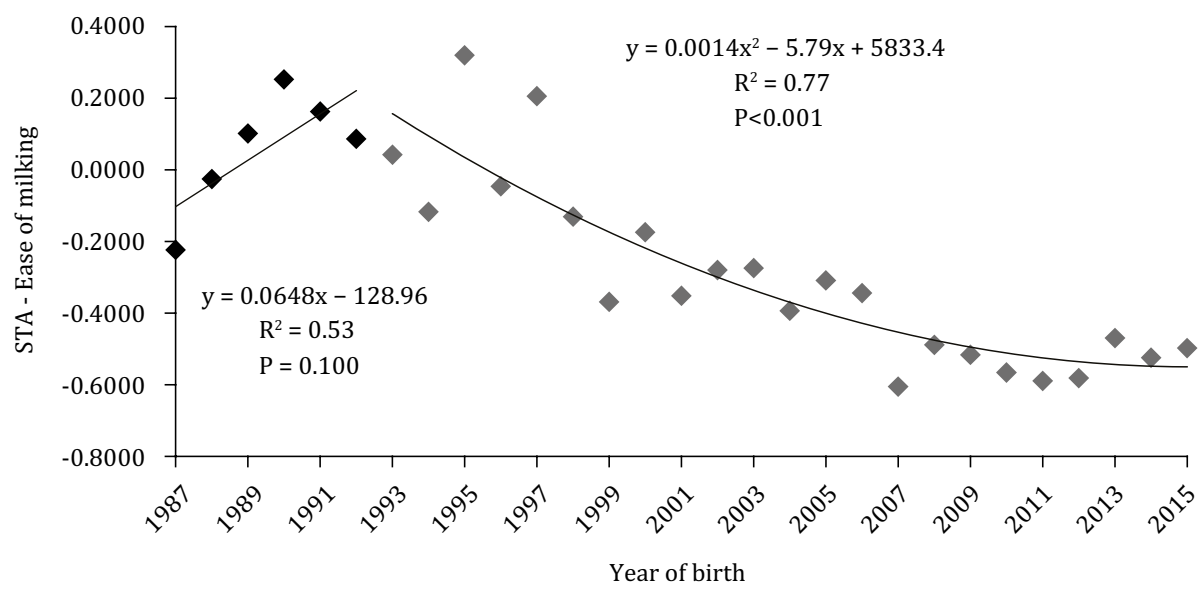

STA - standard transmitting ability.

Figure 7 - Mean Dairy Gir ease of milking STA according to year of birth.

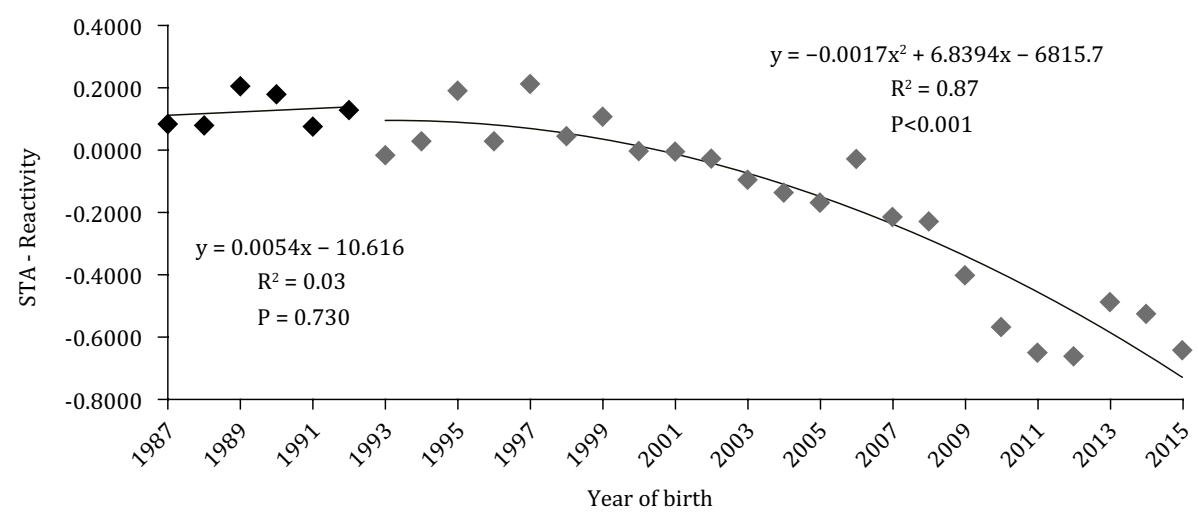

STA - standard transmitting ability.

Figure 8 - Mean Dairy Gir reactivity STA according to year of birth. 
Since it is directly linked to the continuance of an animal in the herd, it has always been the object of selection by dairy breeders. The longevity of dairy cows has great economic weight, whose importance is evident in milk production systems, since the cost of replacing individuals is a great expense to dairy herders (Hazel et al., 2014).

In Dairy Gir population, the top-rated bulls for milk production between 1993 and 2014 did not improve fore udder attachment. In fact, some even had a very negative effect on it. These bulls were used imprudently to mate with a large number of cows, including several that had poor fore udder attachment. The equation presented a negative coefficient $(-0.0006)$, indicating an STA reduction each year. Thus, after the use of tested bulls began in 1993, there was a marked decrease in fore udder attachment STA.

Additionally, there is a negative genetic correlation between milk yield and fore udder attachment (Teodoro et al., 2000; Esteves et al., 2004; Lagrotta et al., 2010). According to Misztal et al. (1992), high selection intensity for milk yield causes losses in some conformation traits, especially those of the mammary system.

This result demonstrates the need for a selection index for the breed, in which traits of great relevance, such as fore udder attachment, would have greater weight in udder composition. Nevertheless, trial runs can make a didactic contribution, pointing out desirable morphological traits to breeders as they consider criteria for the ideal biotype of the breed. Thus, breeding guided by appropriate tools (e.g., STA) can contribute to improvement of traits of animal performance importance.

Increased rear udder height allows a greater capacity for milk storage, providing the necessary anatomical structure to increase production. A relevant factor is the high intensity of selection for milk production. With increased productivity during lactation, the mammary gland has developed, modifying its anatomy (Misztal et al., 1992; Teodoro et al., 2000). Its secretory tissues have begun to occupy a greater volume in the gland and, consequently, the height and width of the rear udder have increased (Norman et al., 1988; Davis et al., 1998).

There was no genetic trend explainable by the regression of mean rear udder height (STA) in the studied population (Figure 3) between 1987 and 1992. The mean rear udder height STA of the breed has improved (quadratic effect) since $1993\left(\mathrm{P}<0.001 ; \mathrm{R}^{2}=0.79\right)$. This genetic advance was probably due to indirect associations related to morphology and milk yield, since there is a positive genetic correlation between these traits (Esteves et al., 2004).

The main morphological feature that interferes with rear udder height is the rump angle. The steeper this angle is in Dairy Gir, the lower the insertion of the rear udder, and vice versa. Since the rump angle has been selected for improvement, rear udder height has also indirectly improved (Lagrotta et al., 2010). This trend was also observed in the Swiss Brown breed by Rennó et al. (2003), who claimed that cows with high pins and wide high rear udders tend to present higher milk yields.

Larger rear udders include larger milk production and storage areas. The rear udder width of Dairy Gir began to accumulate genetic gains after the use of tested bulls began in 1993 (Figure 4), evident in the regression $(\mathrm{P}<0.001)$, which is mainly due to the fact that this trait is of greater genetic and phenotypic correlation with milk yield in dairy breeds (Wenceslau et al., 2000; Lagrotta et al., 2010). Therefore, the use of tested bulls to improve milk yield has also resulted in improved udder width.

Shorter teats have always been desirable, mainly due to the mechanical milking issue. Cows with long teats have greater difficulty with mechanical milking and are more susceptible to injuries, which can compromise the health and integrity of the udder and, consequently, milk quality (dos Santos, 2007). However, Porcionato et al. (2010) analyzed the association between morphometry, external teat length, and somatic cell count in Dairy Gir and found a lower propensity to mastitis in animals with longer teats. Klein et al. (2005) and Paulrud and Rasmussen (2004) also observed that teat length and thickness play an important role in preventing mastitis, since the longer the canal length, the more pronounced the keratin cap, which acts as a natural barrier, preventing contamination with the pathogens that cause mastitis. Therefore, it is important to establish a balance between 
functionality and health for this trait, given that extremes (very long or short teats) are undesirable (Panetto et al., 2017).

Teat length has been the object of great selection pressure by Dairy Gir breeders. The ideal length for the teats of Dairy Gir cows is around $7.5 \mathrm{~cm}$, which facilitates milking. The current mean teat length in Dairy Gir cows is $7.4 \pm 1.8 \mathrm{~cm}$ (Panetto et al., 2017), a value very close to that found by Peixoto et al. (2014) in the Guzerá breed $(7.3 \pm 0.14 \mathrm{~cm})$, but longer than that found by Silva et al. (2014) in the Girolando breed $(5.8 \pm 1.7 \mathrm{~cm})$. Campos et al. (2012) reported that the mean teat length in the Holstein breed is $5 \mathrm{~cm}$. In the present study, reduction in teat length is confirmed (Figure 5). Thus, genetic gains in this trait $(\mathrm{P}<0.001)$ promoted by reduced teat length has been found only since the implementation of the breeding program in 1993, as there was no genetic evolution in teat length prior to this year $(\mathrm{P}=0.942)$. As a highly heritable trait $(0.40 \pm 0.03)$ (Panetto et al., 2017), there was a great response to selection for reduced teat length through tested bulls.

An intermediate to thin teat thickness is the most desirable measure. Overly thick teats impair the milking process and are, therefore, an undesirable trait for the breed (Panetto et al., 2017). Factors such as mechanical milking functionality and improved calf feeding conditions were decisive in the decision to select for this trait, which is of average heritability in Dairy Gir (0.21 \pm 0.03$)$ (Panetto et al., 2017). The current Dairy Gir mean teat thickness is $3.90 \pm 1.00 \mathrm{~cm}$ (Panetto et al., 2017). This value is also very close to that found by Peixoto et al. (2014) in the Guzerá breed $(3.4 \pm 0.01 \mathrm{~cm})$. The mean teat thickness in the Holstein breed is approximately $2.5 \mathrm{~cm}$ (Campos et al., 2012). Given the great genetic variability still evident among Dairy Gir, there is an ongoing need to select for decreased teat thickness. Prior to 1993, there was no linear effect in the evolution of this trait $\left(P=0.691 ; R^{2}=0.04\right)$ (Figure 6). Teat thickness showed a rapid response to selection after $1993\left(\mathrm{P}<0.001 ; \mathrm{R}^{2}=0.64\right)$. Although cows were commonly rejected due to large teat thickness before the use of genetically tested bulls began, there has not since been a significant reduction in this trait.

Ease of milking is related to the time and effort required to milk a cow. Ideal scores are close to 1 , indicating easier, smoother milking (Panetto et al., 2017). Thus, in the late 1990s, directed mating intensified and promoted a linear improvement in this trait $\left(\mathrm{P}<0.001 ; \mathrm{R}^{2}=0.77\right)$ (Figure 7). In Brazil, the spread of mechanical milking among small breeders has required animals that are easier to milk.

The evolution of handling tools such as mechanical milking and the use of oxytocin to stimulate milk secretion may have contributed to improved milking efficiency. There is also an association between ease of milking and reactivity (Lagrotta et al., 2010), since more docile animals can be milked faster (Kramer et al., 2013). This evolution can be observed in the evolution of mean Dairy Gir reactivity (Figure 8). Ideally, animals should score close to 1 (Panetto et al., 2017).

Low reactivity has always been an object of selection by Dairy Gir breeders; however, its heritability is low (0.12 \pm 0.02 ) (Panetto et al., 2017). Although the animals have become more docile in recent years (Figure 8), this may also be associated with improvements in pre- and postpartum management conditions. Furthermore, there is also a tendency for wilder animals to be less productive, since the hormones linked to stress disrupt both milk secretion and production (González, 2002). Since the selection of Dairy Gir has led to greatly increased production, tamed animals have thereby been indirectly selected.

\section{Conclusions}

The use of genetically-tested bulls since 1993 has led to important genetic gains in the Dairy Gir population. Before the identification of genetically-superior bulls began, many traits showed no improvement and some worsened.

Selection for milk yield has modified the morphological traits of the Gir mammary system. Although the mammary gland has become more bulky with better functioning teats, its longevity may be compromised due to the pressure exerted by higher milk volumes on its ligaments. 
Behavioral traits also showed genetic progress, in which the animals became more docile and easier to milk, which is important for more technical production systems.

\section{Conflict of Interest}

The authors declare no conflict of interest.

\section{Author Contributions}

Conceptualization: A.R. Fernandes, L. El Faro, A.E. Vercesi Filho, C.H.C. Machado, E.R. Bittar and M.S. Igarasi. Data curation: A.R. Fernandes, L. El Faro and M.S. Igarasi. Formal analysis: A.R. Fernandes, L. El Faro and M.S. Igarasi. Funding acquisition: M.S. Igarasi. Investigation: A.R. Fernandes, L. El Faro and M.S. Igarasi. Methodology: A.R. Fernandes, L. El Faro and M.S. Igarasi. Project administration: A.R. Fernandes, L. El Faro and M.S. Igarasi. Resources: A.R. Fernandes, L. El Faro and M.S. Igarasi. Software: A.R. Fernandes, L. El Faro, A.E. Vercesi Filho and M.S. Igarasi. Supervision: M.S. Igarasi. Validation: C.H.C. Machado. Visualization: A.R. Fernandes, L. El Faro and L.M. Barbero. Writing-original draft: A.R. Fernandes, L. El Faro and M.S. Igarasi. Writing-review \& editing: L. El Faro, L.M. Barbero and M.S. Igarasi.

\section{Acknowledgments}

This research was supported by Instituto de Estudos Avançados em Veterinária “José Caetano Borges" in the Programa de Pós-graduação em Sanidade e Produção Animal nos Trópicos - Universidade de Uberaba.

\section{References}

Almeida, T. P.; Kern, E. L.; Daltro, D. S.; Braccini Neto, J.; McManus, C.; Thaler Neto, A. and Cobuci, J. A. 2017. Genetic associations between reproductive and linear-type traits of Holstein cows in Brazil. Revista Brasileira de Zootecnia 46:91-98. https://doi.org/10.1590/s1806-92902017000200002

Boldman, K. G.; Kriese, L. A.; Van Vleck, L. D.; Van Tassell, C. P. and Kachman, S. D. 1995. A manual for use of MTDFREML: a set of programs to obtain estimates of variances and covariances [DRAFT]. U.S. Department of Agriculture, Agricultural Research Service, Beltsville.

Campos, R. V.; Cobuci, J. A.; Costa, C. N. and Braccini Neto, J. 2012. Genetic parameters for type traits in Holstein cows in Brazil. Revista Brasileira de Zootecnia 41:2150-2161. https://doi.org/10.1590/S1516-35982012001000003

Davis, S. R.; Farr, V. C.; Copeman, P. J. A.; Carruthers, V. R.; Knight, C. H. and Stelwagen, K. 1998. Partitioning of milk accumulation between cisternal and alveolar compartments of the bovine udder: relationship to production loss during once daily milking. Journal of Dairy Research 65:1-8. https://doi.org/10.1017/S0022029997002562

Dos Santos, M. V. 2007. Estratégias para controle de mastite e melhoria da qualidade do leite. Manole, São Paulo.

Embrapa Gado de Leite. 2005. Sistema linear de avaliação. Embrapa Gado de Leite/ABCGIL, Juiz de Fora.

Esteves, A. M. C.; Bergmann, J. A. G.; Durães, M. C.; Costa, C. N. and Silva, H. M. 2004. Correlações genéticas e fenotípicas entre características de tipo e produção de leite em bovinos da raça Holandesa. Arquivo Brasileiro de Medicina Veterinária e Zootecnia 56:529-535.

Freitas, A. F.; Teixeira, N. M.; Durães, M. C.; Freitas M. S. and Barra R. B. 2002. Parâmetros genéticos para características lineares de úbere, escore final de tipo, produção de leite e produção de gordura na raça Holandesa. Arquivo Brasileiro de Medicina Veterinária e Zootecnia 54:485-491. https://doi.org/10.1590/S0102-09352002000500006

González, F. H. D. 2002. Introdução a endocrinologia reprodutiva veterinária. Universidade Federal do Rio Grande do Sul (UFRGS), Porto Alegre. Available at: <https://www.ufrgs.br/lacvet/site/wp-content/uploads/2017/05/endocrino_rep_ vet.pdf>. Accessed on: Oct. 06, 2017.

Hazel, A. R.; Heins, B. J.; Seykora, A. J. and Hansen, L. B. 2014. Production, fertility, survival, and body measurements of Montbéliarde-sired crossbreds compared with pure Holsteins during their first 5 lactations. Journal of Dairy Science 97:2512-2525. https://doi.org/10.3168/jds.2013-7063

Klein, D.; Flock, M.; Khol, J. L.; Franz, S.; Stüger, H. P. and Baumgartner, W. 2005. Ultrasonographic measurement of the bovine teat: breed differences and the significance of the measurements for udder health. Journal of Dairy Research 72:296-302. https://doi.org/10.1017/S0022029905000920 
Kramer, M.; Erbe, M.; Bapst, B.; Bieber, A. and Simianer, H. 2013. Estimation of genetic parameters for novel functional traits in Brown Swiss cattle. Journal of Dairy Science 96:5954-5964. https://doi.org/10.3168/jds.2012-6236

Lagrotta, M. R.; Euclydes, R. F.; Verneque, R. S.; Santana Júnior, M. L.; Pereira, R. J. and Torres, R. A. 2010. Relação entre características morfológicas e produção de leite em vacas da raça Gir. Pesquisa Agropecuária Brasileira 45:423-429. https://doi.org/10.1590/S0100-204X2010000400011

Leão, G. F. M.; Pivatto, D. R. D.; Carniel, H.; Rodrigues M. G. K.; Braga R. A.; Silva M. R. H. and Teixeira P. P. M. 2013. Melhoramento genético em zebuínos leiteiros: uma revisão. Agropecuária Científica no Semiárido 9:9-14.

Misztal, I.; Lawlor, T. J.; Short, T. H. and VanRaden, P. M. 1992. Multiple-trait estimation of variance components of yield and type traits using an animal model. Journal of Dairy Science 75:544-551. https://doi.org/10.3168/jds.S00220302(92)77791-1

Norman, H. D.; Powell, R. L.; Wright, J. R. and Cassell, B. G. 1988. Phenotypic and genetic relationship between linear functional type traits and milk yield for five breeds. Journal of Dairy Science 71:1880-1896. https://doi.org/10.3168/jds.S0022-0302(88)79758-1

Panetto, J. C. C.; Verneque, R. S.; Silva, M. V. G. B.; Machado, M. A.; Martins, M. F.; Bruneli, F. A. T.; Peixoto, M. G. C. D.; Santos, G. G.; Arbex, W. A.; Faza, D. R. L. R.; Geraldo, C. C.; Machado, C. H. C.; Ventura, H. T.; Pereira, M. A.; Vercesi Filho, A. E.; Maciel, R. S. and Fernandes, A. R. 2017. Programa Nacional de Melhoramento do Gir Leiteiro. Sumário Brasileiro de

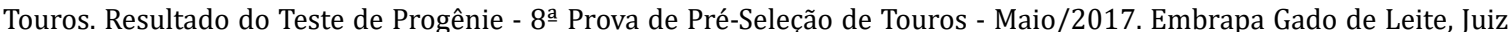
de Fora. Available at: <https://www.embrapa.br/busca-de-publicacoes/-/publicacao/1069047/programa-nacional-demelhoramento-do-gir-leiteiro-sumario-brasileiro-de-touros-resultado-do-teste-de-progenie-8a-prova-de-pre-selecaode-touros---maio-2017>. Accessed on: Dez. 10, 2017.

Paulrud, C. O. and Rasmussen, M. D. 2004. How teat canal keratin depends on the length and diameter of the teat canal in dairy cows. Journal of Dairy Research 71:253-255. https://doi.org/10.1017/S0022029904000056

Peixoto, M. G. C. D.; Bruneli, F. A. T.; Santos, G. G.; Penna, V. M.; Machado, C. H. C.; Verneque, R. S.; Machado, M. A.; Panetto, J. C. C.; Lôbo, R. B. and Carvalho, M. R. S. 2014. Programa Nacional de Melhoramento do Guzerá para Leite Resultados do Teste de Progênie, do Programa de Melhoramento Genético de Zebuínos da ABCZ e do Núcleo MOET. Embrapa Gado de Leite, Juiz de Fora. Available at: <https://www.infoteca.cnptia.embrapa.br/bitstream/doc/986487/1/ D0C168Guzera2014comcapa.pdf >. Accessed on: Oct. 06, 2017.

Porcionato, M. A. F.; Soares, W. V. B.; Reis, C. B. M.; Cortinhas, C. S.; Mestieri, L. and Santos, M. V. 2010. Milk flow, teat morphology and subclinical mastitis prevalence in Gir cows. Pesquisa Agropecuária Brasileira 45:1507-1512. https://doi.org/10.1590/S0100-204X2010001200023

Prata, M. A.; Faro, L. E.; Moreira, H. L.; Verneque, R. S.; Vercesi Filho, A. E.; Peixoto, M. G. C. D. and Cardoso, V. L. 2015. Genetic parameters for milk production traits and breeding goals for Gir dairy cattle in Brazil. Genetics and Molecular Research 14:12585-12594. https://doi.org/10.4238/2015.0ctober.19.2

Rennó, F. P.; Araújo, C. V.; Pereira, J. C.; Freitas, M. S.; Torres, R. A.; Rennó, L. N.; Azevêdo, J. A. G. and Kaiser, F. R. 2003. Correlações genéticas e fenotípicas entre características de conformação e produção de leite em bovinos da raça Pardo-Suíça no Brasil. Revista Brasileira de Zootecnia 32:1419-1430. https://doi.org/10.1590/S151635982003000600017

Saowaphak, P.; Duangjinda, M.; Plaengkaeo, S.; Suwannasing, R. and Boonkum, W. 2017. Genetic correlation and genome-wide association study (GWAS) of the length of productive life, days open, and 305-days milk yield in crossbred Holstein dairy cattle. Genetics and Molecular Research 16(2). https://doi.org/10.4238/gmr16029091

Silva, M. V. G. B.; Martins, M. F.; Paiva, L. C.; Cembranelli, M. A. R.; Arbex, W. A.; Santos, K. C. L.; Panetto, J. C. C.; Carvalho, B. C. and Alves, B. R. C. 2014. Programa de Melhoramento Genético da Raça Girolando. Sumário de Touros. Resultado do Teste de Progênie - Julho/2014. Embrapa Gado de Leite, Juiz de Fora. Available at: <https://www.infoteca.cnptia.embrapa.br/ bitstream/doc/991651/1/DOC170Girolando2014.pdf>. Accessed on: Oct. 06, 2017.

Teodoro, R. L.; Verneque, R. S.; Martinez, M. L.; Cruz, M.; Paula, L. R. O. and Campos, J. P. 2000. Estudo de características do sistema mamário e suas relações com a produção de leite em vacas da raça Gir. Revista Brasileira de Zootecnia 29:131-135. https://doi.org/10.1590/S1516-35982000000100018

Wenceslau, A. A.; Lopes, P. S.; Teodoro, R. L.; Verneque, R. S.; Euclydes, R. F.; Ferreira, W. J. and Silva, M. A. 2000. Estimação de parâmetros genéticos de medidas de conformação, produção de leite e idade ao primeiro parto em vacas da raça Gir Leiteiro. Revista Brasileira de Zootecnia 29:153-158. https://doi.org/10.1590/S1516-35982000000100021 